\title{
A Comprehensive Methodology for Assessing the Quality of Landscape Architecture Study Programmes in European Higher Education Institutions
}

\author{
Gintaras Stauskis, Vilnius Gediminas Technical University, Lithuania \\ Jeroen de Vries, Dutch School of Landscape Architecture, the Netherlands
}

\begin{abstract}
In the light of recent environmental and socio-economic challenges that face the modern urban regions, the implication of current needs for education quality has been discussed. Now a further step for practical actions of re-shaping higher education in Europe takes place. The quality of teaching of landscape architects has a direct impact on the quality of the professional services and their contribution to design, planning and management of urban open spaces, heritage sites and objects, parks and gardens and (green) infrastructure. A wide variety of landscape architecture (LA) study programmes across Europe provide education that differ in scope, content and quality.

Two European landscape associations - the European Council of Landscape Architecture Schools [4] and the International Federation of Landscape Architects (IFLA) Europe developed guidelines for landscape architect's education that covers environmental, engineering and artistic competences and soft skills [4] (IFLA 2008). For IFLA the requirements are a tool for the professional recognition of the programmes. The ECLAS Guidance report (2010) focuses on the core, subject-specific and generic competences that students should acquire in the education process.

This framework with requirements, recommendations and guidelines for LA studies aims to increase the quality of the current landscape architecture studies; beyond that, it is used to develop a common tool for assessing the quality of landscape architecture education at several universities in Europe. The results of the assessment reveal the strengths and the gaps of the analysed study programmes and teaching subjects. The outcomes of this inquiry give a clear picture for the schools which study modules and courses should be improved and how to meet the common requirements. At the same time, the method is used to keep and further develop the strong sides of the study programme at each university. Looking at the bigger picture of LA education in Europe, the map of subject-specific competences in landscape architecture training is further developed, by adding cutting-edge competences that are proposed by the participating universities and professional associations.
\end{abstract}

Keywords: landscape architecture, teaching, competences, education, professional practice

The first landscape architecture (LA) teaching programme was founded in Europe at the Norwegian Agriculture University in 1919 [15]. Now more than one hundred European higher education institutions (HEIs) offer a wide range of Landscape Architecture (LA) study programmes [2]. Although there are common approaches in teaching [5] there are evident differences in content, structure and quality and inequalities between these LA study programmes in the different European regions. The higher education sector including the LA education is undergoing dramatic changes in many European countries where the universities are closing or changing these programmes, while at the other hand some schools are developing new LA study programmes. Economic, demographic, legal and didactic factors trigger the changes that are emerging for the profession in the run of its establishment in different countries. The competences for landscape architecture need to be innovated due to current needs of society and new challenges such as climate change, water management, and sustainability. Therefore, we vitally need a method based on a common European understanding of landscape architecture studies that focuses on jointly developed study requirements. This method could be used for assessing the existing and building the new LA study programmes in order to achieve higher education quality by harmonising the LA studies across the European continent. The improvement of study programmes in this respect may facilitate increased student mobility between the schools and have an impact on easily acquiring the recognition of Landscape Architecture professional qualification in Europe.

This paper presents a method for assessing those aspects of quality that relate to course content (competences), teaching modes, and assessment methods. At the same time, the method can benchmark the structure and scope of current study programmes and subjects for their compliance to the common European requirements for landscape architecture studies. The aim of this research is to test the efficiency and applicability of the developed method by implementing it on a selection of landscape architecture study programmes and 


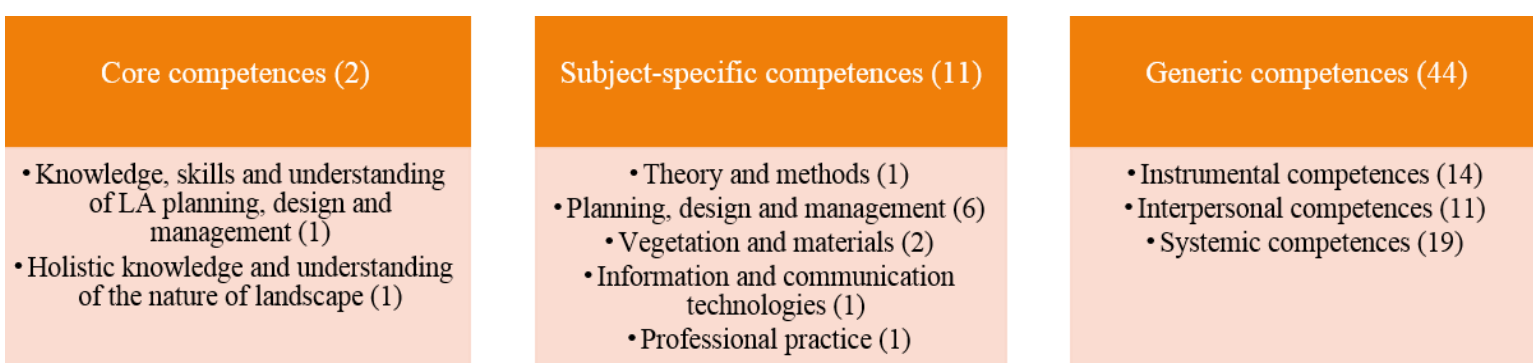

Fig. 1. Amount and categories of core, subject-specific and generic competences in Landscape Architecture [ECLAS 2010]

subjects as a quality assurance tool for gaining insight in their strengths and the gaps. In addition, we use the results to discuss the further application and impact areas of the method on development of new LA study programmes.

The authors have assessed landscape architecture study programmes and subjects at five European universities: Van Hall Larenstein University of Applied Science, the Netherlands (VHL); University of Agriculture in Krakow (URK), Poland; Szent István University in Budapest (SZIE), Hungary; Estonian University of Life Sciences (EMU) in Tartu, Estonia; and Vilnius Gediminas Technical University (VGTU) in Lithuania. The obtained results were analysed and discussed. The survey uses as a basis the academic and professional requirements for the LA education that were developed and adopted by ECLAS and by IFLA Europe in the period of 2008- 2014. The results this study may give an opportunity to revise and amend the guidance documents in Europe if that proves to be reasonable.

The overarching goal of surveying the landscape architecture programmes in participating institutions is to strengthen strategic collaboration and partnership between the universities by harmonising important aspects of the education quality. By obtaining more information on the compliance of the present landscape architecture study programmes at the participating institutions would enable the schools to create the pathway and the timeline for updating the existing study programmes or establishing the new ones in this field. The universities themselves could use the tool for internal quality assessment and monitoring the programme's quality by running it annually or at other preferred frequency. In 1989, European higher education institutions providing training in landscape architecture have associated aiming to provide a platform for collaboration and improving the quality of education of landscape architects across the continent. Similarly, IFLA Europe aims to coordinate landscape architect's professional activities and keeps a careful look on the study programmes that are delivered across the European continent.

\section{Background and literature}

As landscape architecture is an extremely diverse profession overarching the ecologic, social, artistic and other fields of activity, the diversity of the professional field is also the main challenge for studies, research and professional practice including assessment of these activities [6]. The question if one assessment system can test different university programmes in different countries is raised in the context of the global trend of evaluating education quality [8]. Authorities, universities and even media measure the quality of existing study programmes worldwide in many different ways. Some assessment methods suggest doing the assessment by analysing the study outcomes as student's drop-off, exam failure, employability of graduates and similar empiric information instead of assessing the curricula. Assessment of the education and training process has become a common practice in many fields of professional activities, and complex methods are used to do that. The CIPP method (context - input - process - product) is pointed out as being universally acceptable for assessing the quality in the terms of construct validity of education programmes in many different fields, adjusting it to the area specifics [12]. In this case, exploratory factor analysis and confirmatory factor analysis may be used to identify the desirable training subjects. In this and many other cases, the quantitative indicators are derived from the qualitative assessment for being objectively comparable and valid for discussion. Critical review is essential for the assessment of any process, so that goes also for a study programme. Some outstanding researches in this field outline the importance of critical thinking as a progress driver for the teachers, students and for the whole of the education process [17].

Two European landscape architecture associations - ECLAS and IFLA Europe have developed a set of guidelines for landscape architecture studies. The IFLA UNESCO Charter for Landscape Architecture Education(2008) defines the education qualifications needed to practice the profession based on the diverse needs of the society and sets several quality criteria for landscape 
architecture education focusing on the practical studio work, and the relation between teaching, practice, and research [9]. It also advises academic institutions on creating self-assessment systems as a tool for continuous quality assurance. The IFLA Charter on Landscape Architecture Education gives the main education objectives and emphasises the need for exchange programmes between the teachers and the students at an advanced level [10]. Guidance requirements for landscape architecture studies in Europe [4] cover environmental, engineering, artistic and interpersonal competences that learners acquire in the education process. In particular, it presents the complex of multiple professional, academic and generic competences (Fig. 1).

There are two core competences and eleven subject-specific competences that directly relate to the discipline of landscape architecture; the forty-four generic competences are more general applicable and comprise for instance aspects of communication, leadership, and ICT skills [4]. Researchers point out the interdependency between the quality of study programmes and their delivery, on one hand, and the quality of outcomes, on the other. University-managed internships as a part of education process in many cases proved to be an efficient way for the students to prepare for professional practice [1]. Researchers constantly debate about the relation of academic education and the real life practice where certain analysis and research methods acquired in the study process are essential [15], and that is an important aspect for assessing the quality of any study programme. After the implementation of a new developed or renewed (part of a) study programme it is important to survey the student's experience and expectations of the outcomes of academic education. Studies reveal that students have different study habits and preferences, depending on their background and situation. For instance, nontraditional students (adults, mid-career students, students working for a second degree, etcetera) prefer a larger share of individual assignments to group work [7]. Modern ICT-based learning tools can be used to help solving the needs of some groups by introducing distant learning, simulation, gaming and the other teaching methods that are preferred by the students.

The aspect of interaction between the subjects of neighbouring education programmes is pointed out as having impact on the quality of study outcomes [11] therefore this aspect could be a part of the course design and assessment methods. Modules that integrate working together with other disciplines or making use of knowledge and skills of various disciplines can contribute to developing an interdisciplinary perspective. Research that focuses on the contents of education in landscape architecture and other design fields shows the need to evaluate how the process-oriented assignments balance with the result-oriented assignments in developing student's creativity as well as productivity [13]. For that, different teaching methods are used, and their variety creates an optimal teaching climate. For landscape architecture, the studio or the practical design exercise are key learning methods because these offer a context for learners to construct their own learning process in a collaborative way [5]. There should be a variety of assessment methods to evaluate the learning process and study outcomes that were supported by different teaching methods. Legal requirements in each country regulate the registration and evaluation procedures of study programmes including the joint and double-degree study programmes. The legal acts that regulate this process set the rules more for the procedures and little for the quality of the study programmes. As an example, the general requirements for joint study programmes in Lithuania [14] mainly focuse on the procedures, documentation and formalities and very little on the content and quality.

As it comes from the background analysis, the assessment methods that different universities, authorities and researcher's groups currently use to evaluate the quality of landscape architecture and the other creative discipline's study programmes demonstrate a wide array of tools, accounting for the large number of criteria in the variety of aspects in their own different ways. Comparing the results of such assessment seems hardly possible as these methods differ too much and do not aim to become a universal assessment method applicable for a number of schools at any area or a region. In most of cases, university staff create and use a self-designed assessment method as a part of formally required self-assessment procedures. In this context, two ideas arise for the recent research. First, developing a universal assessment method and an easy-to-use practical assessment tool would enable more schools and their staff to analyse and evaluate the quality of education programmes in landscape architecture. Second, there is a need to deliver a functional assessment system based on a regionally e.g. Europe-wide accepted system of qualities and values to validate the quality of education programmes in landscape architecture across the European continent and beyond that. The outcomes of assessment that are designed for improving the education quality should be used for that purpose, and are not intended to be taken up in regulation, used for decisions on funding programmes or other purposes that do not focus on quality of education. 


\section{Methodology and its application}

We created a universal method for assessing the quality of bachelor and master study programmes in landscape architecture based on the internationally accepted quality requirements and presented the results in a common visual form. The method uses the experience and the achievements of the East Baltic Network of Landscape Architecture Schools (EBANELAS www.ebanelas.org) [3] and follows a set of consecutive steps. It comprises the assessment tool that we have built according to the European quality requirements for landscape architecture competences [4], the self-assessment process executed by each participating school, and the analysis and interpretation of the results done by the authors of this paper.

The assessment tool features the list of 49 competences consisting of core (2), subjectspecific (11) and generic (30) competences that the guidance document presents [4]. The core competences (C) cover the core knowledge, understanding and skills of planning, design and management that a specialist need to conserve the existing or create the new landscapes. It also covers the holistic understanding of the nature of landscape. The subject-specific (SS) competences are the main professional abilities that a student is supposed to acquire during his or her studies. The SS competences include theory and methods, skills for planning, design and management, urban opens space, cultural landscapes, infrastructure projects, information and communication technologies and the abilities to apply these skills in a professional practice. The 30 generic competences $(\mathrm{G})$ include the instrumental, interpersonal and systemic competences. After carefully analysing the teaching processes and programmes at the participating schools, on one hand, and the professional practice specifics, on the other hand, in the EBANELAS academic collaboration (East 2014) we extended the list of generic competences and added 14 additional competences: four instrumental, three interpersonal, and seven systemic competences. These additions serve to secure the abilities needed for landscape architecture professionals in the constantly changing situation; such as the ability of spatial thinking, ability to present ideas graphically, knowledge of legal and administrative context and knowledge of socio-economic and environmental context. As social skills are more and more important for a creative and productive teamwork [13] we extended the set of interpersonal competences by adding the ability to accept criticism, ability to manage conflicts and ability to manage public participation.

Teaching programmes consist of modules and teaching subjects form a complex system where one can measure the elements by their number and by their scope in ECTS. For this reason, we assessed the compliance to the European study requirements for two aspects - the number of modules or subjects that address a specific competence, and in the number of ECTS that the modules or subjects addressing that competence contain. This allows obtaining results that are more reliable and develop recommendations that reflect the actual situation. For each participating institution, all teaching modules and courses of the programme were listed in the assessment tool on the $\mathrm{Y}$-axis, then the qualitative requirements of the Guidance document [4] were listed in the X-axis. The combinations resulted in a quantitative assessment of the running landscape architecture programmes (four programmes) and teaching subjects (one programme). The academic staff of the five participating universities analysed their own teaching programmes, the teaching process and the contents of each module or a subject taught and based on that responded to the assessment questions. If a particular competence (X-axis) is more likely developed in the assessed course unit of the programme (Y-axis) the response was yes and 1 is inserted, if it is more likely that the particular competence is not developed in the programme the response was no and 0 is inserted.

To evaluate the occurence of the teaching methods used to deliver each module or a course we listed all teaching methods that are most frequently used in landscape architecture education: studio, lectures and seminars, study trips, practical work, internship, e-learning and self-study (ECLAS 2010), and passed this list to the local assessment teams. In the same way, the academic staff of four universities assessed each module or a course against the list of teaching methods: the course that was delivered by a specific teaching method scored one, the course that did not use that method scored zero. Consequently, we listed the most frequent assessment methods used to evaluate each module or course: exam, test, poster presentation, essay, report, project diary, and sketchbook. The occurence of each assessment method in a study module or a course was done in the same way by assigning the grades one or zero for each module or course (Tab. 3). While compiling the results of teaching methods assessment into one table we obtained information which teaching methods are used most and least in the assessed study programmes for LA teaching.

It is important to underline that the number of modules or courses and ECTS were different for each programme as the local teams were assessing the current landscape architecture programmes, modules and courses. We compiled all data into a common analysis sheet, processed the information by deriving the answers to the questions of this research for each study programme (e.g. VGTU, Fig. 2., 3.), compared the average results between the participating universities (Fig. 4, 5), and derived the recommendations for improvement based on the common issues. 


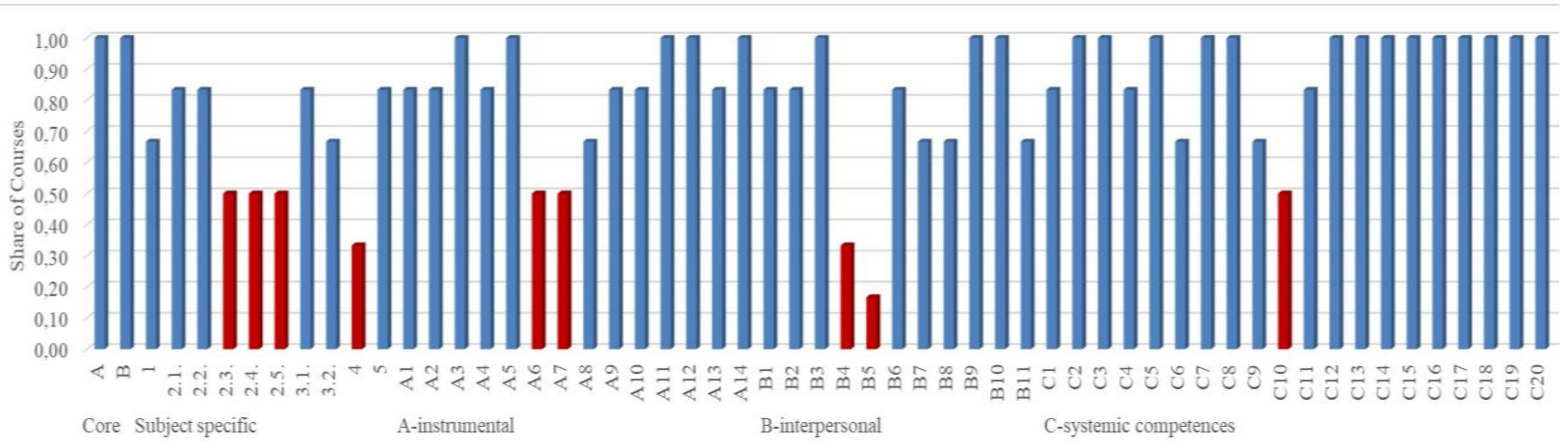

Fig. 2. Share of courses that develop a specific competence (Core - AB, Subject Specific 1-5, Instrumental A, Interpersonal B and Systemic C) in VGTU BArch 2017 [created by the authors]

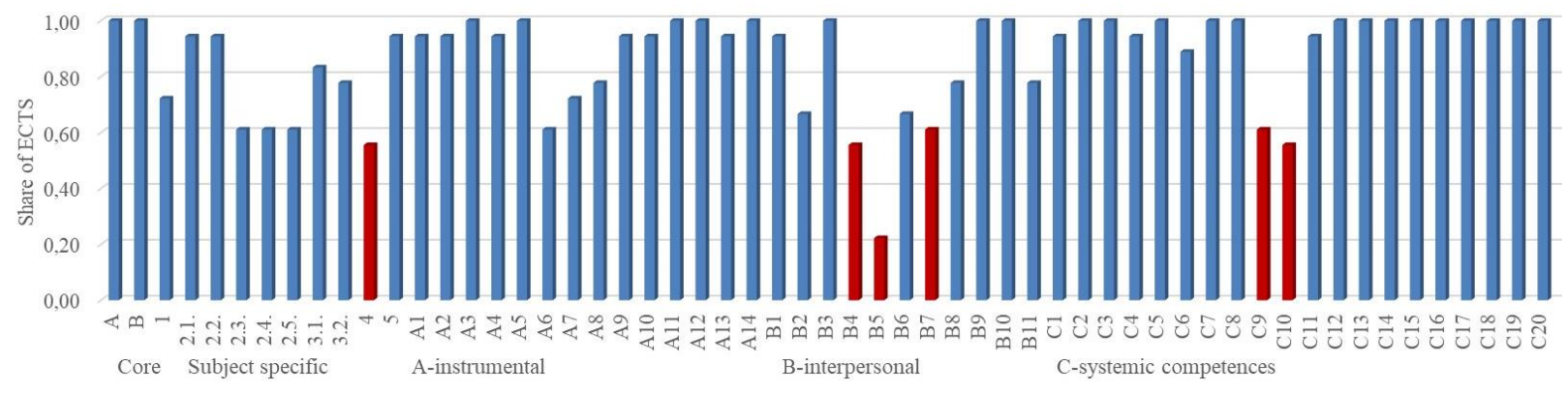

Fig. 3. Share of ECTS that develop a specific competence (Core - AB, Subject Specific 1-5, Instrumental A, Interpersonal B and Systemic C), VGTU BArch 2017 [created by the authors]

For each study programme, we derived the overall average share of the modules or courses that develop certain competences and based on that we determined the minimum threshold as $50 \%$ of the average share that marks the line below which the academic staff should improve the modules or courses to address the identified competences. The minimum threshold is different for every study programme as is the average share of modules or courses. In the graphs, we indicated the modules or courses below the threshold in red and figured out which competences are least addressed in all assessed programmes for each study programme and for all assessed programmes taken together (Table 1). This outlines the study areas that universities should upgrade to address better certain competences in LA studies.

\section{Results and Discussion}

Using the VGTU Bachelor of Architecture (BArch) programme as an example, we present the layout of the share of modules or courses (Fig. 2) and the share of ECTS (Fig. 3) that the schools have assigned for developing a specific competence. The results of assessing all programme's matching teaching methods (Fig. 4) and the applied assessment methods (Fig. 5) are illustrated below.

Figure 2 shows that the subject specific competences Interpretation and Conservation / Management of Cultural Landscapes (2.3), Conservation and Management of Parks and Gardens (2.4), Planning and Design for
Infrastructure Projects and Landscape Impacts (2.5), the instrumental competences Knowledge of second language (A6) and Elementary computing skills (A7) and the systemic competence Initiative and entrepreneurial spirit $(\mathrm{C} 10)$ are only taught in $50 \%$ of the courses. The subject-specific competence Information Technology in LA (4) and the interpersonal competence Ability to work in interdisciplinary team (B4) are only acquired in $30 \%$ of the courses. The results show that the interpersonal competence Ability to communicate with experts in other fields (B5) is only part of a small share of the courses in VGTU BArch study programme.

Figure 3 shows that the subject-specific competence Information Technology in LA (4), the interpersonal competence Ability to work in an interdisciplinary team (B4), the systemic competences Project design and management (C9) and Initiative and entrepreneurial spirit (C10) is learned in $50 \%$ of the ECTS of the programme. The results also show that the interpersonal competence Ability to communicate with experts in other fields (B5) get relatively little attention by the amount of ECTS $(20 \%)$ in the study programme.

By summarising the assessment results for all study programmes, we identified which are the least addressed competences in the study programmes (Table 1). Low occurence frequency we can see for the interpersonal (generic) (24) and subject-specific (22) competences. There are eight competences identified that are the least addressed in 
The core, subject specific and generic competences that the programmes address below the threshold [created by the authors]

\begin{tabular}{|c|c|c|c|c|c|c|c|c|c|c|}
\hline \multirow{3}{*}{$\begin{array}{l}\text { University } \\
\text { progr., } \\
\text { threshold }\end{array}$} & \multirow{2}{*}{\multicolumn{2}{|c|}{ Core }} & \multirow{2}{*}{\multicolumn{2}{|c|}{ Subject-specific }} & \multicolumn{6}{|c|}{ Generic } \\
\hline & & & & & \multicolumn{2}{|c|}{ A Instrumental } & \multicolumn{2}{|c|}{ B Interpersonal } & \multicolumn{2}{|c|}{ C Systemic } \\
\hline & Courses & ECTS & Courses & ECTS & Courses & ECTS & Courses & ECTS & Courses & ECTS \\
\hline $\begin{array}{c}\text { VGTU } \\
0,71\end{array}$ & - & - & $\begin{array}{c}2.3,2.4 \\
2.5,4\end{array}$ & 4 & 6,7 & - & 4,5 & $4,5,7$ & 10 & 9,10 \\
\hline $\begin{array}{c}\text { EMU } \\
0,45\end{array}$ & - & - & $\begin{array}{c}2.2,2.3 \\
2.4,2.5, \\
3.1,3.2, \\
\quad 4\end{array}$ & $\begin{array}{l}2.2, \\
2.3, \\
2.4, \\
2.5, \\
3.1, \\
3.2\end{array}$ & 6,8 & 6 & $4,6,7$ & 4,7 & $\begin{array}{c}6,7,9 \\
10\end{array}$ & $\begin{array}{c}6,7 \\
10\end{array}$ \\
\hline $\begin{array}{l}\text { URK } \\
0,35\end{array}$ & - & - & $\begin{array}{c}2.2,2.3 \\
2.4\end{array}$ & $\begin{array}{l}2.3 \\
2.4\end{array}$ & 6,13 & 6 & $\begin{array}{c}2,4,6 \\
7,8,10 \\
11\end{array}$ & $2,4,7$ & $6,7,10$ & $\begin{array}{c}6,7 \\
10\end{array}$ \\
\hline $\begin{array}{l}\text { SZIE } \\
0,41\end{array}$ & - & - & $\begin{array}{l}2.5,3.1, \\
3.2,4,5\end{array}$ & 4,5 & $6,7,13$ & $\begin{array}{c}3,6 \\
7,11 \\
13\end{array}$ & $1-11$ & $1-11$ & $\begin{array}{c}6,7,9 \\
10,19 \\
20 \\
\end{array}$ & $6,7,9$ \\
\hline $\begin{array}{l}\text { VHL } \\
0,42\end{array}$ & A & B & $\begin{array}{c}2.3,2.4 \\
4,5\end{array}$ & $\begin{array}{c}2.3 \\
2.4,5\end{array}$ & - & - & - & - & - & - \\
\hline $\begin{array}{c}\text { Least } \\
\text { addressed } \\
\text { competen } \\
\text { ces } \\
\text { (common } \\
\text { mention) }\end{array}$ & & & $\begin{array}{c}2.3-4 \\
\mathbf{2 . 4}-\mathbf{4} \\
\mathbf{4}-\mathbf{4} \\
2.5-2 \\
5-2\end{array}$ & $\begin{array}{c}2.3- \\
3 \\
2.4- \\
3 \\
4-2\end{array}$ & $6-4$ & $6-3$ & $4-4$ & $4-4$ & $\begin{array}{c}6-3 \\
7-3 \\
\mathbf{1 0}-\mathbf{4} \\
9-2\end{array}$ & $\begin{array}{c}6-3 \\
7-3 \\
10-3\end{array}$ \\
\hline $\begin{array}{l}\text { Number } \\
\text { of } \\
\text { competen } \\
\text { ces below } \\
\text { threshold }\end{array}$ & 1 & 1 & 22 & 14 & 9 & 7 & 24 & 19 & 14 & 11 \\
\hline
\end{tabular}

TABLE 2

The least addressed competences in LA bachelor studies for all assessed programmes [created by the authors]

\begin{tabular}{|c|c|c|c|}
\hline No. & Competence's segment & Title of the competence & Frequency \\
\hline 1 & \multirow{3}{*}{ Subject-specific } & $\begin{array}{l}\text { 2.3. Interpretation and conservation / management of cultural } \\
\text { landscapes }\end{array}$ & 7 \\
\hline \multirow[t]{2}{*}{2} & & 2.4. Conservation / management of parks and gardens & 7 \\
\hline & & 4. Information and communication technologies in LA & 6 \\
\hline 4 & A. Instrumental & 6. Knowledge of a second language & 7 \\
\hline 5 & B. Interpersonal & 4. Ability to work in an interdisciplinary team & 8 \\
\hline 6 & \multirow{3}{*}{ C. Systemic } & 6. Leadership & 6 \\
\hline 7 & & 7. Understanding of cultures and customs of other countries & 6 \\
\hline 8 & & 10. Initiative to succeed and entrepreneurship skills & 7 \\
\hline
\end{tabular}

LA bachelor studies of the assessed programmes (Table 2). In Figure 4, the teaching methods that are used in the courses are presented. In most cases, more than one teaching method occurs in a specific module or course. For instance, a module on Urban open space planning is delivered as a studio in which students collaborate, which is combined with a series of lectures, some excursions and e-learning. For this reason, the percentage for each teaching method reflects the overall share of modules or courses that use this particular method for teaching. The analysis results show that studio learning, lectures and seminars, excursions, and internship are the most used teaching methods, while e-learning, 


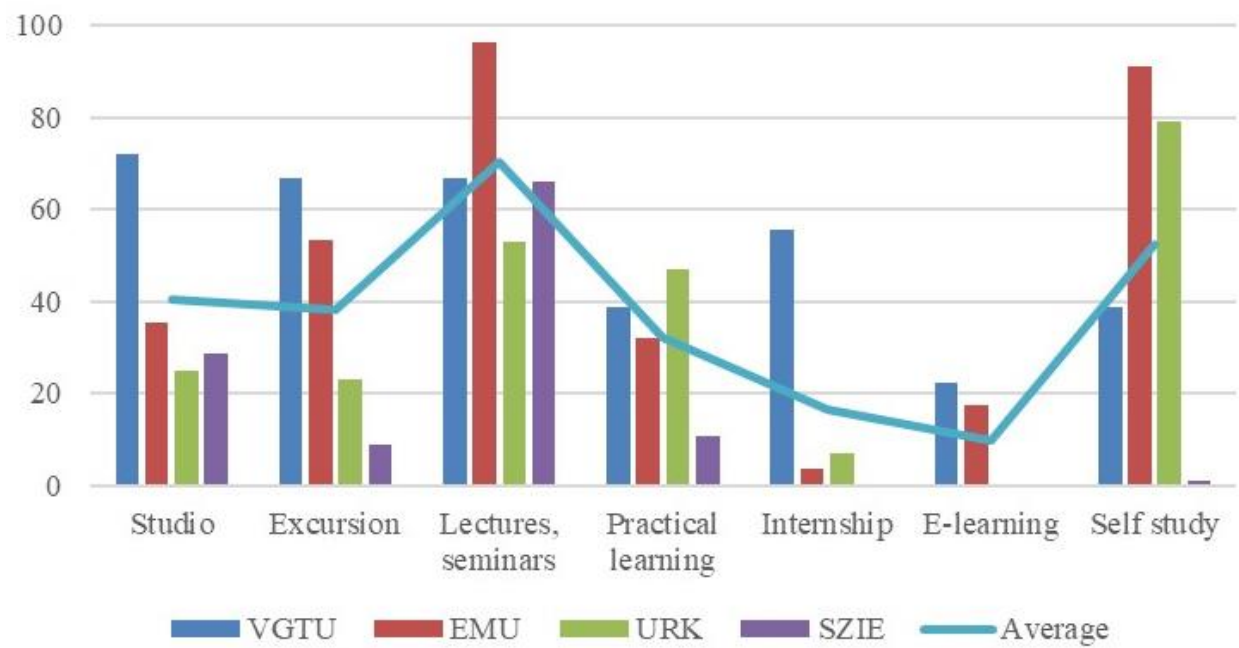

Fig. 4. Percentage of courses in which each teaching method is applied for all programmes. BArch 2017. [created by the authors]

TABLE 3

The share (\%) of ECTS for teaching methods in LA bachelor studies for all assessed programmes [created by the authors]

\begin{tabular}{|c|l|c|c|c|c|c|c|c|}
\hline No. & $\begin{array}{l}\text { University } \\
\text { programme }\end{array}$ & Studio & Excursion & $\begin{array}{c}\text { Lectures, } \\
\text { seminars }\end{array}$ & $\begin{array}{c}\text { Practical } \\
\text { learning }\end{array}$ & Internship & E-learning & Self-study \\
\hline 1 & VGTU & $\mathbf{7 2 , 2}$ & $\mathbf{6 6 , 7}$ & $\mathbf{6 6 , 7}$ & 38,9 & $\mathbf{5 5 , 6}$ & $\mathbf{2 2 , 2}$ & 38,9 \\
\hline 2 & EMU & 35,5 & 53,5 & $\mathbf{9 6 , 5}$ & 32,0 & 3,5 & 17,4 & $\mathbf{9 1 , 3}$ \\
\hline 3 & URK & 25,0 & 23,0 & 53,0 & $\mathbf{4 7 , 0}$ & 7,0 & 0 & 79,0 \\
\hline 4 & SZIE & 28,6 & 8,9 & 66,0 & 10,8 & 0 & 0 & 1,0 \\
\hline & $\begin{array}{l}\text { Average } \\
(\%)\end{array}$ & 40,3 & 38,0 & $\mathbf{7 0 , 6}$ & 32,2 & 16,5 & $\mathbf{1 0 , 0}$ & 52,6 \\
\hline
\end{tabular}

self-study and practical work are the least used teaching methods for VGTU BArch programme.

The results of the teaching methods assessment demonstrate that the programmes most frequently employ lectures and seminars as a main teaching method, while e-learning is least used - just $10 \%$ of ECTS are taught by this method (Table 3). Studio, excursions and practical learning take the basic share of ECTS for LA teaching $-32 \%$ to $40 \%$. There is a great variety of the used teaching methods between the different programmes. For instance VGTU teaches $72,2 \%$ of ECTS by the studio method while URK - just 25\%. Similarly, EMU has assigned 91,3\% ECTS for self-study while SZIE - just $1 \%$. A relatively small share of ECTS are acquired via elearning so this might be considered a common issue where partner universities could join forces to develop more efficient material delivered by elearning. On the other hand, studio and practical learning essentially comply with ECLAS requirements to cover $50 \%$ or more of the whole study time. Quite unequal amount of self-study is an issue for some programmes (SZIE - \%) that together with e-learning is considered a main pathway to individually constructed and self-managed education process [16].

The survey of the applied assessment methods shows that the poster presentation is the most frequently used assessment method; on the contrary, evaluating an essay is the least used. Inequality between the programmes is relatively great: SZIE uses test in 46,8\% ECTS and VGTU - 0 ECTS. VGTU requires a project diary in $66,7 \%$ ECTS while EMU and URK-0\%. It is naturally understandable that theory courses are usually assessed by an exam or test, while studios mainly by poster presentations, project diaries with in some cases a sketchbook. The share of exams and tests as assessment methods may illustrate the share of theoretical part of the programme; that is the largest for SZIE and EMU; while poster presentations and project diaries can illustrate the practical teaching methods in the programme, that occur most frequent in VGTU and EMU.

The EBANELAS method appears an efficient tool for assessing individual study programmes and figuring out the gaps that the programme needs to fix based on the ECLAS guidance requirements. 


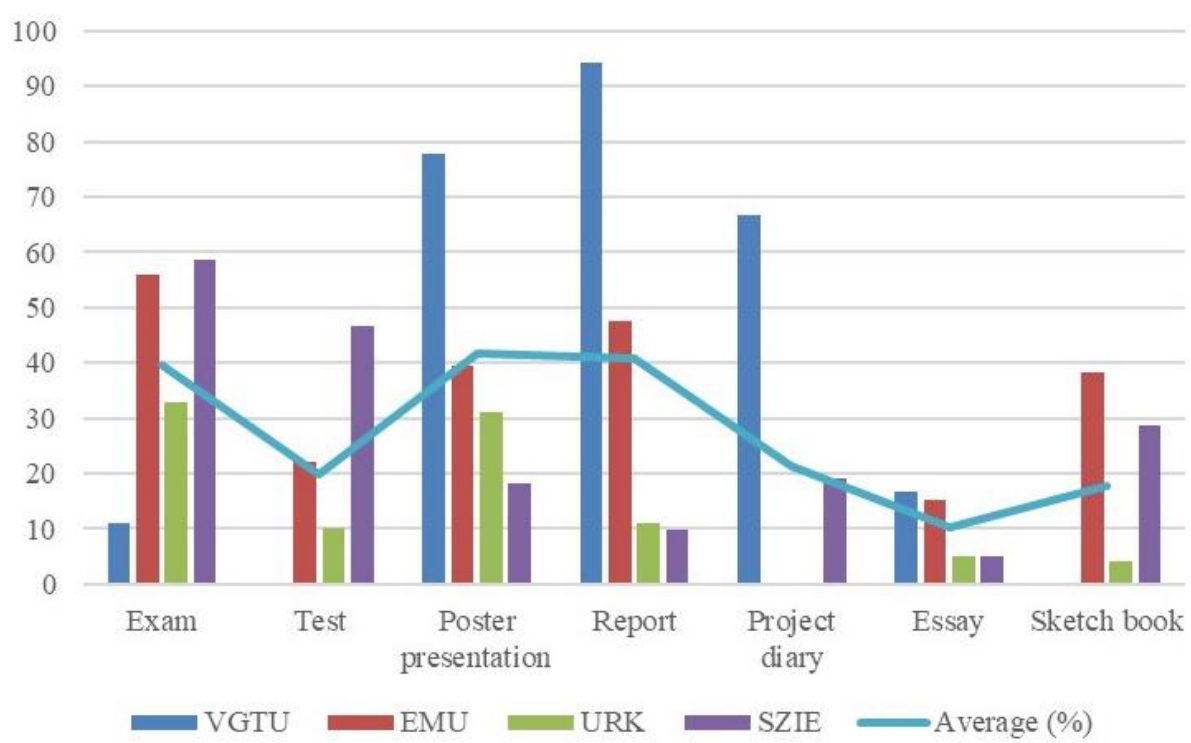

Fig. 5. Percentage of courses that use each assessment method for all programmes BArch 2017. [created by the authors]

The share (\%) of ECTS for assessment methods in LA bachelor studies [created by the authors]

\begin{tabular}{|c|l|c|c|c|c|c|c|c|}
\hline No. & $\begin{array}{l}\text { University } \\
\text { programme }\end{array}$ & Exam & Test & $\begin{array}{c}\text { Poster } \\
\text { presentation }\end{array}$ & Report & $\begin{array}{c}\text { Project } \\
\text { diary }\end{array}$ & Essay & Sketch book \\
\hline 1 & VGTU & 11,1 & 0 & $\mathbf{7 7 , 8}$ & $\mathbf{9 4 , 4}$ & $\mathbf{6 6 , 7}$ & $\mathbf{1 6 , 7}$ & 0 \\
\hline 2 & EMU & 55,8 & 22,1 & 39,5 & 47,7 & 0 & 15,1 & $\mathbf{3 8 , 4}$ \\
\hline 3 & URK & 33,0 & 10,0 & 31,0 & 11,0 & 0 & 5,0 & 4,0 \\
\hline 4 & SZIE & $\mathbf{5 8 , 6}$ & $\mathbf{4 6 , 8}$ & 18,2 & 9,9 & 19,2 & 4,9 & 28,6 \\
\hline & $\begin{array}{l}\text { Average } \\
(\%)\end{array}$ & 39,6 & $\mathbf{1 9 , 7}$ & $\mathbf{4 1 , 6}$ & 40,8 & 21,5 & $\mathbf{1 0 , 4}$ & 17,8 \\
\hline
\end{tabular}

It also turns out to be efficient for assessing and comparing several programmes and identify the gaps in each of them (Table 1). More, it is efficient to figure out the gaps that are in common for the number of programmes in LA education. This feature has a wider European importance. First, because trans-national cooperation may help developing the commonly needed teaching contents - modules or supporting courses - for universities in Europe. In this case, it is indicated that for five programmes there is a need to upgrade the development of the eight competences listed in Tab. 2. Second, it may help building a completely new LA study programme that would be fully compliant with the ECLAS Guidance requirements. In this case, the EBANELAS method may act as a self-assessment tool while building and pilot testing the programme. Third, the methodology may help initiating a common training framework for LA studies in Europe by establishing an open network of the universities that run the LA study programmes that have been upgraded by the assessment results as demonstrated in this paper.

\section{Conclusions}

The common assessment methodology that is based on the internationally elaborated and agreed guidance requirements and recommendations enables the schools to carry out a self-assessment, improvement and benchmarking. The analysis of the present LA study programmes was performed in a group of five universities, and it has revealed the common gaps in LA studies that the schools confront such as developing entrepreneurship skills and ICT skills. Bridging these gaps requires an effort by the school's faculty which is challenging, time consuming and requires staff commitment and development. The group of collaborating universities or a defined network can share these tasks by jointly developing special study modules for the issues outlined by using the developed methodology. Other aspects that influence the quality of LA studies, such as the available staff or facilities and infrastructure (plant-assortment garden and ICT-studios), were not yet included in the 
method. These could be added to the method or be part of a separate evaluation system to be developed.

ECLAS, IFLA Europe, EBANELAS and partner organisations and networks may offer a platform that initiates the collaboration and builds social capital for fostering better quality of landscape architecture education. The collaborative upgrade process may virally spread across the European continent as soon as the first universities go through the illustrated process and demonstrate the benefits. In addition, universities developing new LA study programmes may use this methodology for achieving high-quality teaching outcomes right from the start of the study programme. Certainly, staff should be psychologically and professionally ready to accept the required changes and lead the study process forward, and by doing that, a country or a region may develop a common strategy for the whole education sector.

\section{References}

1. Barbarash D. Knowledge and skill competency values of an undergraduate university managed cooperative internship program: A case study in design education. Asia-Pacific Journal of Cooperative Education, 2016, Vol. 17, No 1, p. 21-30.

2. Birli, B. From Professional Training to Academic Discipline. The Role of International Cooperation in the Development of Landscape Architecture at Higher Education Institutions in Europe. PhD Thesis, TU-Vienna, 2016, p. 162-191.

3. East Baltic Network of Landscape Architecture Schools EBANELAS [online 15.4.2018.]. http://www.ebanelas.org/

4. ECLAS Guidance on Landscape Architecture Education. European Council of Landscape Architecture Schools. Richard Stiles and others (eds). LE: NOTRE project of ECLAS, 2010, p. 15-40.

5. Fetzer, E. Knowledge Building in Landscape Architecture: A Pedagogical Action Research Study with International Online Seminars. PhD thesis, Kassel: Kassel University Press, 2014, p. 26-35; 49-54. ISBN 978-3-86219-548-0

6. Galan, J. Bridging the Gap. A Reflection on the Doctoral Colloquium. Journal of Landscape Architecture (JoLA), 2017, Vol. 12, No 1. http://doi.org/10.1080/18626033.2017.1301300

7. George, B., Bussiere, S. M. Non-Traditional Students and Design Studio Pedagogy: How Can We Make the Design Studio More Inclusive? 8th International Conference of Education, Research and Innovation Seville (ICERI). Spain 2015, 18-20 November. IATED: 2015. ISBN: 978-84-608-2657-6 / ISSN: 2340-1095

8. Guttenplan D. D. Comparing Different Countries' Universities: Can One Test Fit All? The Global Edition of the New York Times, July 22, 2013.

9. IFLA/UNESCO Charter for Landscape Architecture Education, 2012 [cited 06.04.2018.]. http://iflaonline.org/wpcontent/uploads/2014/11/IFLA-Charter-for-Landscape-Architectural-Education-Revised-2012.pdf

10. IFLA Charter for Landscape Architecture Education. Addenda to IFLA Charter for Landscape Architectural Education When Implemented in the European Region. 2008 [cited 06.04.2018.]. www.iflaonline.org

11. Kaleli, E., Mutdogan, S. Interaction between Design Educations: The Example of "Edirne Workshop". 2nd International Multidisciplinary Scientific Conference on Social Sciences and Arts (SGEM 2015). Albena, BULGARIA. Stef 92 Technology Ltd. 2015, p. 477-483.

12. Kang, J., Park, K. O. Development of Evaluation Indicators for Hospice and Palliative Care Professionals Training Programs in Korea. Journal of Continuing Education in the Health Professions, 2017, Vol. 37, Issue 1, p. 19-26.

13. Özkan, D. G., Alpak, E. M., Duzenli, T. Developing Creativity in Design Education: Landscape Architecture Environmental Design Studio Work. Third International Conference on Education and Social Sciences (Intcess 2016). Istanbul, Turkey 2016, 8-10 February, p. 352-359.

14. The General Requirements of Joint Study Programmes. The order No. V-65 of the Minister of Education and Science of the Republic of Lithuania of February 3, 2014 [cited 06.04.2018]. www.smm.lt

15. Research in Landscape Architecture. Methods and methodology [Van den Brink, A., Bruns, D., Tobi, H., Bell, S., eds.). London and New York: Routledge, 2017, p. 1-8. ISBN 978-1-138-02093-1.

16. Vygotsky, L. Thought and Language, Revised and Expanded Edition. Cambridge: MIT Press, 1986. ISBN-10: 0262720108

17. Willingham, D. T. Critical thinking: Why is it so hard to teach? American Educator, 2007. Vol. 31(2), p. 8-19.

\section{Acknowledgements}

The authors carried out this research by a support from the European Union Education Exchange Foundation Lithuania.

\section{INFORMATION ABOUT THE AUTHORS:}

Gintaras Stauskis is a Doctor of the Humanities in Architecture and a professor at Vilnius Gediminas Technical University (Lithuania). He is lecturing and researching at the Department of Urban Design. He is involved in the European Union research and academic programmes on landscape education, green building and sustainable urbanism. His current research fields include landscape architecture and planning, 'green' urban architecture and mobility, accessibility of environment, recreation and urban health. His research results are presented in numerous national and international publications and conferences. Currently he is leading the Erasmus+ project "Trans-National Education of Landscape Architects". He is a board member at the Lithuanian Green Building Council. More publications at: https://vgtu.academia.edu/GintarasStauskis 
Jeroen de Vries (1953) is a dedicated landscape architect with a mission to foster the professional and academic quality of the discipline. Combines vision and innovation with management and sustainable support of organisations. In groups and projects acting as the driving spirit: structuring, organising discussion, guiding decision making, supporting colleagues, and editing and implementing the outcomes. He graduated as a landscape architect of Wageningen University with a specialisation in landscape design and ecology. A landscape architect registered by law, member of the NVTL and ECLAS, and an international member of ASLA. Currently affiliated with the LE:NOTRE Institute.

Kopsavilkums. N̦emot vērā nesenās vides un sociālekonomiskās problēmas, ar ko saskaras mūsdienu pilsētu reǵioni, tiek padziḷināti pētita izglîtības kvalitātes ietekme. Tiek veikts vēl viens solis praktiskām darb̄̄ibām, kas vērstas uz augstākās izglîtības pārveidošanu Eiropā. Ainavu arhitektu mācību kvalitāte tiešã nozīmē ietekmē profesionālo pakalpojumu kvalitāti un to ieguldījumu pilsētu publisko telpu, kultūras mantojuma vietu un objektu, parku, dārzu un infrastruktūras projektěšanā, plānošanā un vadīšanā. Plašas ainavu arhitektūras (LA) studiju programmas visā Eiropā nodrošina izglītību, kas atšḳiras pēc darbības jomas, satura un kvalitātes.

Divas Eiropas ainavu asociācijas - Eiropas Ainavu arhitektūras skolu padome (ECLAS) un Starptautiskā ainavu arhitektu federācija (IFLA) izstrādājusi ainavu arhitekta izglìtības vadlīnijas. Tās attiecas uz vides, mākslas un inženierzinātņu kompetenci un prasmi. Attiecībā uz IFLA prasībām, tiek veidota studiju programmu profesionāla atzišsana. ECLAS vadlīniju ziṇojumā (2010) galvenā uzmanība tiek pievērsta tematiskajām un vispārīgajām kompetencēm, kuras studentiem vajadzētu apgūt izglîtības procesā. Minētās studiju vadlīnijas ir vērstas uz pašreizējo ainavu arhitektūras studiju kvalitātes uzlabošanu, turklāt tas tiek izmantots, lai izstrādātu vienotu instrumentu, un lai varētu novērtēt ainavas arhitektūras izglîtības kvalitāti Eiropas universitātēs. Novērtējuma rezultāti parāda analizēto studiju programmu un mācību priekšmetu stipro pusi un nepiln̄ibas. Izpētes rezultāti sniedz skaidru priekšstatu par skolām, kurās jāuzlabo mācību moduḷi un kursi, kā arī lai izpildītu kopējās prasības. Tajā pašã laikā šo metodi izmanto, lai turpinātu un attīstītu katras universitātes studiju programmas stiprās puses. Apskatot plašāk LA izglīīibu Eiropā, ainavu arhitektūras mācību priekšmetu specifiskā kompetence tiek tālāk attīstīta, papildinot jaunākos atzinumus, ko piedāvā iesaistītās universitātes un profesionālās asociācijas.Autori ir novērtējuši ainavu arhitektūras studiju programmas un priekšmetus piecās Eiropas universitātēs: Van Hall Larensteina Lietiškāās zinātnes universitāte, Nīderlande (VHL); Lauksaimniecības universitāte Krakovā (URK), Polija; Szent István Università Budapest (SZIE), Ungārija; Igaunijas Dzīvības zinātṇu universitāte (EMU) Tartu, Igaunija; un Viḷnas Gediminas Tehniskā universitāte (VGTU) Lietuvā. Iegūtie rezultāti tika analizēti un apspriesti. Aptaujā tiek izmantotas akadēmiskās un profesionālās prasības LA izglīî̄bai, kuras izstrādāja un pieņēma ECLAS un IFLA Europe 2008.-2014. gadā. Rezultāti tiek apkopoti, lai pārskatītu un grozītu vadlīniju dokumentus.

Katrai studiju programmai tika atrasti moduḷi vai studiju programmu kopējā dą̣a, kas veido noteiktas kompetences, un, pamatojoties uz to, tika noteikts minimālais slieksnis. Tika izveidota $50 \%$ robežlīnija, kas norāda akadēmiskajam personālam nepieciešamību studiju programmas uzlabošanā, lai atrisinātu jauno speciālistu kompetences līmeni. Minimālais slieksnis katrai studiju programmai ir atšḳirīgs, tāpat kā vidējā moduḷu vai kursu daḷa. Pētījuma grafiskā sadạ̦ā ir norādīti moduḷi vai kursi, kuru kvalitātes līmenis ir zem sarkanās līnijas. Pētījumā ir nolasāmas studiju jomas, kuras universitātēm vajadzētu uzlabot.

Šajā rakstā sniegta metode, kā novērtēt kvalitātes aspektus, kas saistīiti ar kursa saturu un studiju procesu. Tajā pašā laikā šĩ metode izmantojama, salīdzinot pašreizējo studiju programmu, priekšmetu struktūru un apjomu, lai tas atbilstu kopējām Eiropas prasībām ainavas arhitektūras studijās. Pêtījuma mērkis ir pārbaudīt izstrādātās metodes efektivitāti un pielietojamību, to īstenojot ainavu arhitektūras studiju programmās. IFLA harta nodrošina ainavu arhitektūras izglîtības galvenos mērķus un uzsver vajadzību pēc apmainas programmām starp pasniedzējiem un studentiem augstākajā līmenī. 